http://jmscr.igmpublication.org/home/ ISSN (e)-2347-176x ISSN (p) 2455-0450 crossref DOI: https://dx.doi.org/10.18535/jmscr/v9i6.38

\title{
Relationship between Job anxiety and their Associated Factors-A Cross- Sectional Study among Residence of Garments Workers
}

\author{
Authors \\ Dr Kalpita Biswas ${ }^{1}$, Dr Monira Akhter Moni ${ }^{2}$, Dr Mintu Chowdhury ${ }^{3}$, \\ Dr Md. Mahmudul Hasan ${ }^{4}$, Dr Shafiur Rahman ${ }^{5}$, Dr Irin Hossain ${ }^{6 *}$, \\ Dr Manzurul Haque $\operatorname{Khan}^{7}$ \\ ${ }^{1,3,7}$ Directorate General of Health Services (DGHS), Mohakhali, Dhaka \\ ${ }^{2}$ Colonel Malek Medical College, Manikganj \\ ${ }^{4,5,6}$ National Institute of Preventive and Social Medicine (NIPSOM), Mohakhali, Dhaka \\ *Corresponding Author \\ Dr Irin Hossain
}

\begin{abstract}
Bangladesh is the second largest exporter of garments in the world and garments industry is a major employer in Bangladesh. But garments workers faced many problems like low salary, heavy workload, compulsory overtime, job insecurity etc. This was a cross sectional study conducted to determine the job anxiety among the garments workers from January to December 2017. By Convenience sampling method total 138 samples were interviewed at residence of garments workers near Chittagong Export Processing Zone (CEPZ). Data were collected by obtaining informed written consent of the garments workers by face to face interview using a semi structured questionnaire and Job Anxiety Scale (JAS). It was found that most of the respondents (71.74\%) were female. The age of the respondents was between 18-50 years and the average age was 27.75 ( \pm 8.030$)$ years. Maximum $(63.8 \%)$ respondents were married. Majority (64.1\%) of the male and $42.4 \%$ of the female respondents had education level secondary. The average monthly income was Tk. 8800 ( \pm 5611.53$)$. All the respondents were working as permanent employee in their present work place, half of the respondents (50.7\%) were working as Machine Operator and average working hours in a day was $8.24( \pm 0.65)$ hours. Most of them $(89.9 \%)$ had to work overtime and average duration of overtime per day was $2.56( \pm 1.054)$ hours. It was found that all of the respondents were suffering from job anxiety either it was low or high. Majority (73.2\%) of the respondents had low level of job anxiety. All of them had job related worries and worries about the job security and future. Job anxiety was more common in 31 years age or more. Both high (73\%) and low (71.3\%) job anxiety was common among female workers.
\end{abstract}

Keywords: Level of Job Anxiety, Garments Workers, Export Processing Zone (CEPZ), Job anxiety and their Associated Factors.

\section{Introduction}

Garments sector has been playing an important role in enhancing Bangladesh economy. The sector draws global attention for its quality production. Bangladesh is the second largest exporter of garments in the world ${ }^{1}$. The export oriented garment industry is a major employer in Bangladesh. In 2000, it provided jobs to 1.8 million workers -1.5 million of whom were women. In 1980, there were about 50 garment factories in the country ${ }^{2}$. At present there 
are 5,400 factories in the country and almost 4 million workers, of whom $80 \%$ are woman ${ }^{3}$. About 60 million to 75 million people are employed in the textile, clothing and footwear sector worldwide. About three quarters of garment workers worldwide are female. These jobs lack social protection and conditions in many of the factories are below international standards. Wage levels are generally lower than those in the rest of the domestic manufacturing sector. This is due both to the presence of a large reserve of unskilled female labor in the countryside willing to work for low wages in the garment factories (one of the few modern employment opportunities open to them) and to the absence of collective bargaining or other mechanisms for enforcing the national minimum wage and other labor protections ${ }^{4}$.

In 2003, local researchers calculated that women workers in seven garment factories in Dhaka, the capital city, worked an average of 80 hours overtime per month and that overtime pay was around 60-80 per cent of what they were due. This under-payment was estimated to be the equivalent of 24 hours of uncompensated work per month. In addition, the women workers faced out-of-pocket expenses when forced to work overtime at night, since they could not walk home as in daylight. Night-time transport costs added up to the equivalent of 17 hours of uncompensated work per month $^{5}$. While the women workers knew that they were being underpaid for their overtime, they had not received written pay slips and were not aware of the extent of their under-payment. The main problems faced by garments worker are- lower wages, no leisure time, torture (physically and mentally), negative outlook to them of the society.

American Psychological Association (APA) defined anxiety is an emotion characterized by feelings of tension, worried thoughts and physical changes. People with anxiety disorders usually have recurring intrusive thoughts or concerns. They may avoid certain situations out of worry. They may also have physical symptoms such as sweating, trembling, dizziness or a rapid heartbeat. Anxiety can be either stimulus related (state anxiety) or general in nature (trait anxiety). It presents in different ways including as worry, phobic reactions and panic attacks.

The nature of workplace influences is two sided: the workplace can exert positive effects on wellbeing by providing social support, identity, and self esteem, but it also involves demands pressures and even threats that can provoke anxiety. Job anxiety can occur as a co-morbid disorder and thus a complication in general mental disorder, but also as a stand-alone disorder ${ }^{6,7}$. Job anxiety is associated with a rather negative perception of the workplace ${ }^{8}$. There are several potentially anxiety provoking characteristics at work which must be considered when exploring workplace characteristics and demands. Working people are often together at their workplace with colleagues in groups. They see each other daily on narrow space, e.g. in offices and pass a great part of their day time together. Thus it is normal that social conflicts may arise the more one is exposed to colleagues. There is often no possibility to avoid these conflicts. "Pack behavior and pecking order', it means the natural fight for one's own social rank in a group, competitions behavior between group members ${ }^{9}$, as well as the inborn signals of social endangerment like gaze and body language ${ }^{10}$ can have an anxiety provoking effect. Also, interactions with supervisors may be viewed as potentially anxiety provoking. This is due to the supervisor's hierarchical position with controlling and sanctioning functions ${ }^{11}$. For supervisors, even coworkers offer anxiety provoking potential, as they can sabotage the supervisor's plans, show counter productive work behavior $^{12}$, arise to become competition, engage in a rulebook slowdown, or appear aggressive towards the supervisor. Different demands for achievement or supervisors controlling of achievements can be perceived as threatening. Having experienced or even imagining failing in work tasks is an unconditional anxiety provoking stimulus. It may be that work duties exceed the persons' capacities, or that the work amount is enduringly too high. High requirements at work are especially perceived as stressful when they come along with low 
possibilities for control and low social support ${ }^{13}$. In case of enduring experience of bad success, anxiety of failing can grow. Beside conflicts with colleagues, there may be also endangerment by third parties, like verbal or physical assaults by patients, students, clients, or raids. Professionals like fire fighters, police men, psychiatry nurses or bank employees are especially exposed to dangerous thirds ${ }^{14}$. Beside social threats, there are accidents or other endangerments by the work environment, e.g. allergens or chemical substances ${ }^{14,15}$. On the one hand these may really contribute to health problems or on the other hand they may trigger anxiety concerning health endangerment. Experiencing low control and insecurity is also an unconditional anxiety-provoking stimulus. At the workplace there may be low scope of action or low job control and lacks of transparency which restrict control perception and may provoke anxiety. Examples are the uncertainty of who will be the next for transfer or downsizing, or the introduction of new technologies ${ }^{16}$ or even wide reaching changes like company closure or merger17. Moreover, daily minor hassles of uncertainty like poor reliability of work equipment, or lack of information, or sudden change of work duties can provoke worries and tension. Also subjectively perceived workplace insecurity may be a source of threat and stress.

Occupational status of a job has shown to be associated with work functioning and mental health: compared to persons in low graded jobs, for persons in higher graded jobs absence rates are lower (Christensen et al., 2008) and mental health is better $^{18}$.

Traditionally, the focus of occupational health and safety initiatives has been on chemical, biological and physical exposures, whilst the psychosocial risks at work are still largely neglected and their causes and consequences still insufficiently understood as they pertain to the developing country context $^{19}$.

Job anxieties follows a pattern of reactions that occurs when workers are presented with work demands not matched to their knowledge, skills or abilities and which challenge their ability to cope.
The study is designed to determine the job anxiety among the garments workers. The study also aims at assessment of level of job anxiety among the garments workers, find out the factors related to job anxiety and to identify the socio-demographic status among the garments workers

\section{Materials and Methodology}

A cross-sectional study was conducted to determine the job anxiety among garments workers. The study was conducted during January 2017 to December 2017 at residential area near Chittagong Export Processing Zone (CEPZ), Chittagong. The study population included garments workers in production unit aged more than 18 years, both male and female and working for more than a year. The workers who were on treatment for mental health problems were excluded from the study. The estimated final sample size was 138. Convenient sampling technique was used for this study. Garments workers who were willing to participate and fulfilled the selection criteria were taken as sample. Pre testing was done before data collection. Before the interview, the detail of the study was explained to each eligible respondent and Data was collected by face to face interview using a Bengali semi structured questionnaire after obtaining informed written consent by maintaining confidentiality.

\section{Results}

The cross sectional study was conducted to find out the level of job anxiety among garments workers. Data were collected from 138 garments workers at residential area near Chittagong Export Processing Zone (CEPZ) by using semi structured questionnaire and Job Anxiety Scale (JAS). Data were cleaned, edited and analyzed using Statistical Package for Social Sciences (SPSS). The analyzed data were presented in this chapter through tables and graphs. The results were organized into following sections.

1. Socio-demographic and economic characteristics of the respondents.

2. Factors related to job anxiety. 
Table 01: Distributions of the respondents by their Socio-demographic Conditions

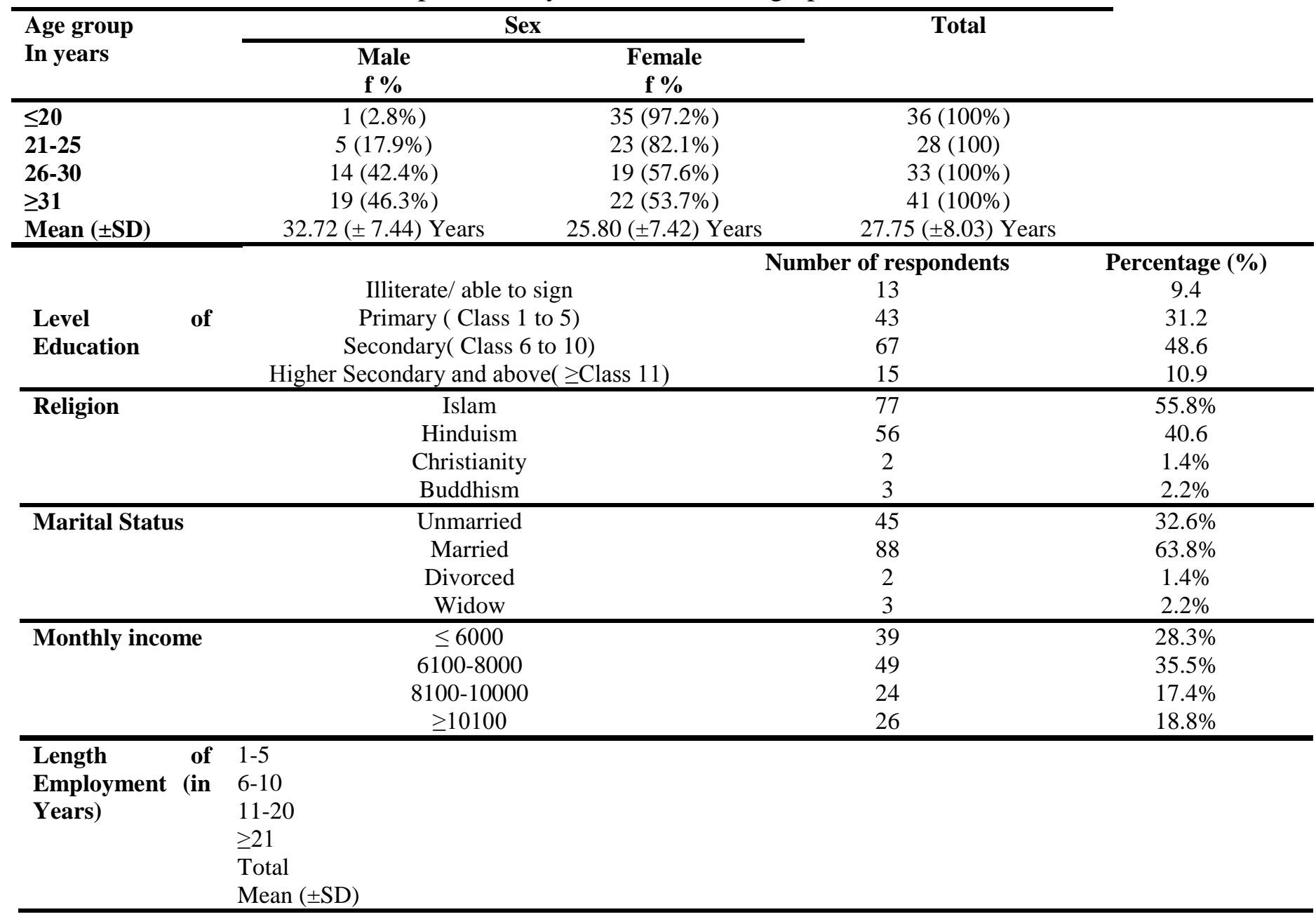

Table 2: Distribution of respondents by different factors and level of job anxiety

\begin{tabular}{|c|c|c|c|c|}
\hline \multicolumn{2}{|r|}{ Respondents by } & \multicolumn{2}{|c|}{ Level of job anxiety } & \multirow[t]{2}{*}{ Test Statistics } \\
\hline & & Low job anxiety & $\begin{array}{c}\text { High job } \\
\text { anxiety }\end{array}$ & \\
\hline Age & $\begin{array}{l}\leq 20 \\
21-25 \\
26-30 \\
\geq 31\end{array}$ & $\begin{array}{l}26(25.7 \%) \\
23(22.8 \%) \\
24(23.8 \%) \\
28(27.7 \%) \\
\end{array}$ & $\begin{array}{c}10(27 \%) \\
5(13.5 \%) \\
9(24.3 \%) \\
13(35.1 \%) \\
\end{array}$ & $\begin{array}{c}\chi 2=1.666 \\
\mathrm{df}=3 \\
\mathrm{p}=0.645\end{array}$ \\
\hline $\operatorname{sex}$ & $\begin{array}{c}\text { Male } \\
\text { Female }\end{array}$ & $\begin{array}{l}29(28.7 \%) \\
72(71.3 \%)\end{array}$ & $\begin{array}{l}10(27 \%) \\
27(73 \%)\end{array}$ & $\begin{array}{c}\chi 2=0.038 \\
\mathrm{df}=1 \\
\mathrm{p}=0.846\end{array}$ \\
\hline level of education & $\begin{array}{c}\text { Illiterate/ Able to sign } \\
\text { Primary (Class } 1 \text { to 5) } \\
\text { Secondary (Class } 6 \text { to } 10) \\
\text { Higher Secondary and above ( } \geq \text { Class } 11)\end{array}$ & $\begin{array}{c}6(5.9 \%) \\
31(30.7 \%) \\
53(52.5 \%) \\
11(10.9 \%) \\
\end{array}$ & $\begin{array}{l}7(18.9 \%) \\
12(32.4 \%) \\
14(37.8 \%) \\
4(10.8 \%)\end{array}$ & $\begin{array}{c}\chi^{2}=6.063 \\
\mathrm{df}=3 \\
\mathrm{p}=0.109\end{array}$ \\
\hline $\begin{array}{l}\text { number of family } \\
\text { members }\end{array}$ & $\begin{array}{l}\leq 3 \\
4-5 \\
\geq 6\end{array}$ & $\begin{array}{l}35(34.7 \%) \\
40(39.6 \%) \\
26(25.7 \%)\end{array}$ & $\begin{array}{l}13(35.1 \%) \\
20(54.1 \%) \\
4(10.8 \%)\end{array}$ & $\begin{array}{c}\chi^{2}=4.080 \\
\mathrm{df}=2 \\
\mathrm{p}=0.130\end{array}$ \\
\hline $\begin{array}{l}\text { As only earning } \\
\text { member }\end{array}$ & $\begin{array}{l}\text { Yes } \\
\text { No }\end{array}$ & $\begin{array}{l}17(16.8 \%) \\
84(83.2 \%)\end{array}$ & $\begin{array}{l}4(10.8 \%) \\
33(89.2 \%)\end{array}$ & $\begin{array}{c}\chi^{2}=0.761 \\
\mathrm{df}=1 \\
\mathrm{p}=0.383\end{array}$ \\
\hline monthly income & $\begin{array}{c}\leq 6000 \\
6100-8000 \\
8100-10000 \\
\geq 10100\end{array}$ & $\begin{array}{l}24(23.8 \%) \\
36(35.6 \%) \\
20(19.8 \%) \\
21(20.8 \%)\end{array}$ & $\begin{array}{l}15(40.5 \%) \\
13(35.1 \%) \\
4(10.8 \%) \\
5(13.5 \%)\end{array}$ & $\begin{array}{c}\chi 2=4.720 \\
\mathrm{df}=3 \\
\mathrm{p}=0.194\end{array}$ \\
\hline
\end{tabular}




\begin{tabular}{|c|c|c|c|c|}
\hline $\begin{array}{l}\text { monthly family } \\
\text { income }\end{array}$ & $\begin{array}{c}6000-10000 \\
10100-15000 \\
15100-20000 \\
20100-50000 \\
\end{array}$ & $\begin{array}{l}17(16.8 \%) \\
32(31.7 \%) \\
28(27.7 \%) \\
24(23.8 \%)\end{array}$ & $\begin{array}{c}7(18.9 \%) \\
13(35.1 \%) \\
11(29.7 \%) \\
6(16.2 \%)\end{array}$ & $\begin{array}{c}\chi 2=0.915 \\
\mathrm{df}=3 \\
\mathrm{p}=0.822\end{array}$ \\
\hline $\begin{array}{l}\text { length } \\
\text { employment }\end{array}$ & $\begin{array}{c}1-5 \\
6-10 \\
11-20 \\
\geq 21 \\
\end{array}$ & $\begin{array}{c}71(70.3 \%) \\
23(22.8 \%) \\
6(5.9 \%) \\
1(1 \%) \\
\end{array}$ & $\begin{array}{c}24(64.9 \%) \\
10(27 \%) \\
2(5.4 \%) \\
1(2.7 \%) \\
\end{array}$ & $\begin{array}{c}\chi^{2}=1.400 \\
\mathrm{df}=3 \\
\mathrm{p}=0.723\end{array}$ \\
\hline $\begin{array}{l}\text { position } \\
\text { present } \\
\text { place }\end{array}$ & $\begin{array}{c}\text { Helper } \\
\text { Machine Operator } \\
\text { Cutter } \\
\text { Iron man/ Lady } \\
\text { Packing man/ Lady } \\
\text { Others }\end{array}$ & $\begin{array}{c}17(16.8 \%) \\
51(50.5 \%) \\
4(4.0 \%) \\
2(2.0 \%) \\
2(2.0 \%) \\
25(24.8 \%)\end{array}$ & $\begin{array}{c}7(18.9 \%) \\
19(51.4 \%) \\
2(5.4 \%) \\
0(0.0 \%) \\
0(0.0 \%) \\
9(24.3 \%)\end{array}$ & $\begin{array}{c}\chi 2=1.212 \\
\mathrm{df}=5 \\
\mathrm{p}=0.997\end{array}$ \\
\hline $\begin{array}{l}\text { working } \\
\text { per day }\end{array}$ & $\begin{array}{l}\leq 8 \\
>8\end{array}$ & $\begin{array}{l}90(89.1 \%) \\
11(10.9 \%)\end{array}$ & $\begin{array}{c}28(75.7 \%) \\
9(24.3 \%)\end{array}$ & $\begin{array}{c}\chi^{2}=3.943 \\
\mathrm{df}=1 \\
\mathrm{p}=0.04\end{array}$ \\
\hline overtime & $\begin{array}{l}\text { Yes } \\
\text { No }\end{array}$ & $\begin{array}{l}90(89.1 \%) \\
11(10.9 \%)\end{array}$ & $\begin{array}{c}34(91.9 \%) \\
3(8.1 \%)\end{array}$ & $\begin{array}{c}\chi^{2}=0.230 \\
\mathrm{df}=1 \\
\mathrm{p}=0.631\end{array}$ \\
\hline $\begin{array}{l}\text { reason } \\
\text { overtime }\end{array}$ & $\begin{array}{c}\text { Compulsory } \\
\text { Heavy workload } \\
\text { Emergency shipment } \\
\text { For extra income }\end{array}$ & $\begin{array}{c}61(67.8 \%) \\
14(15.6 \%) \\
3(3.3 \%) \\
12(13.3 \%)\end{array}$ & $\begin{array}{c}25(73.6 \%) \\
8(23.5 \%) \\
0(0.0 \%) \\
1(2.9 \%)\end{array}$ & $\begin{array}{c}\chi 2=4.126 \\
\mathrm{df}=3 \\
\mathrm{p}=0.218\end{array}$ \\
\hline
\end{tabular}

\section{Discussions}

The study revealed that, among the 138 respondent about $72 \%$ were female and $28 \%$ were male. In a study shown that $35.71 \%$ respondents were female and $64.29 \%$ were male. It is not similar because in this study in military organization where male were predominant but in garment industries most of the workers are female ${ }^{20}$.

In age group less or equal to 20 years maximum $(97.2 \%)$ were female and in age group more or equal to 31 years, $46.3 \%$ were male. A study shown that the mean age was $37.97( \pm 10.7)$ years ${ }^{8}$.

Nearly half of the respondents $(48.6 \%)$ had education level secondary, $31.2 \%$ had primary and $10.9 \%$ had education level higher secondary and above and only $9.4 \%$ were illiterate or able to sign. It was found that the level of education of the respondents were Secondary school (10 school years) 8\%, High School (13 school years) 10\%, Apprenticeship 55\% and University Diploma $27 \%{ }^{6}$.Among the respondents, $89.9 \%$ had to work overtime. About $67 \%(n=124)$ of the respondents had to work overtime for 2 hours per day. The reason of overtime of $69.4 \%$ of the respondents was compulsory, $17.7 \%$ had to work overtime due to heavy workload, $10.5 \%$ for extra income and only $2.4 \%$ for emergency shipment. In 2003, local researchers calculated that women workers in seven garment factories in Dhaka, the capital city, worked an average of 80 hours overtime per month. Low job anxiety was more common among female $(71.3 \%)$ than male $(28.7 \%)$. High job anxiety was also more common among female $(73 \%)$ than male (27\%). Chi-square test was done to see the association. It was not significant $(\chi 2=0.038, p$ $>0.05$ ). In a study shown that female (mean $=43.12$, $\mathrm{SD}=5.30$ ) have more high job anxiety than male $(\text { mean }=18.90, \mathrm{SD}=9.26)^{10}$. Both low $(52.5 \%)$ and high (37.8\%) level of job anxiety were higher in the secondary level of education of the respondents. There was no significant difference in the level of job anxiety in terms of level of education $(\chi 2=$ $6.063, \mathrm{p}=0.109)$. In number of family member group less or equal to 3 , high job anxiety was higher (35.1\%) than low job anxiety (34.7\%). High job anxiety was $54.1 \%$ that was higher than low job anxiety (39.6\%) in 4 to 5 group of family members. In more or equal to 6 family members group high job anxiety was lower (10.8\%) than low job anxiety (25.7\%) A chi-square test indicated no significant 
association between number of family members and level of job anxiety $(\chi 2=4.080, \mathrm{p}=0.130)$. Low job anxiety was lower (16.8\%) in respondents identified as only earning member than those who were not only earning member $(83.2 \%)$ in the family. High job anxiety was higher $(89.2 \%)$ in respondents who were not only earning member than those who were only earning member $(10.8 \%)$ in the family. There was no significant difference in the level of job anxiety in terms of only earning member $(\chi 2=$ $0.761, \mathrm{p}=0.383$ ).

Low job anxiety (50.5\%) and high job anxiety (51.4\%) both were higher in respondents, those who were working as a Machine Operator in present workplace than others positions like supervisors, program manager manger. So it was revealed that job anxiety were more common in workers than senior officers. In some studies it was seen that, occupational status of a job has shown to be associated with work functioning and mental health: compared to persons in low graded jobs, for persons in higher graded jobs absence rates are lower ${ }^{21}$ and mental health is better ${ }^{18}$. About $89.1 \%$ respondents had low job anxiety those who were working overtime than who didn't work overtime. High job anxiety was more common (91.9\%) in the respondents those who were working overtime than who didn't work overtime. There was no significant difference in between level of job anxiety and overtime $(\chi 2=0.230, \mathrm{p}=0.631)$. Respondents who had to do compulsory overtime were higher proportion of low job anxiety $(67.8 \%)$ and high job anxiety $(73.5 \%)$ than other reasons of overtime. Chi-square test shown no significant difference between reason of overtime and level of job anxiety $(\chi 2=4.126, \mathrm{p}=0.218)$.

\section{Conclusions}

A cross sectional study was conducted in residential area near Chittagong Export Processing Zone (CEPZ) to determine the level of job anxiety among the garments workers. During the study period it was found that, majority of the respondents were female and level of education of most of the respondents were secondary. Most of the respondents had to work with heavy workload and compulsory overtime but did not get the proper salary. It is seen that, all of the respondents were suffering from job anxiety either it was low or high. Low job anxiety was more common than high job anxiety in garments workers. All of the respondents had job related worries and worries about the job security. Female workers had higher job anxiety than male and job anxiety was common in respondents working as machine operator. In this study, significant statistical association was found between job anxiety and working hours per day.

\section{Declarations}

Funding: This research protocol was self-funded.

Conflict of Interest: No competing interests relevant to this study to disclose for all authors. Full forms submitted and on file for all authors.

Ethical Approval: The objectives and importance of the research were explained to all participants prior to recruitment. Participation in the study was voluntary. The confidentiality of the participants was maintained, and written informed consent as well as ascent was obtained from all participants. The study was approved by the Institutional Review Board (IRB) of the National Institute of Preventive and Social Medicine (NIPSOM) and obtained an ethical clearance waiver from same source.

\section{References}

1. BGMEA, Bangladesh Apparel \& Safety Exposition, Chittagong 2015.

Available at

https://www.bgmea.com.bd/index.php/page/

Bangladesh_Apparel_and_Safety_Expositio $\mathrm{n}$

2. Kabeer, N and Mahmud, S. (2004). Rags, Riches and Women Workers: Exportoriented Garment Manufacturing in Bangladesh Chains of Fortune: Linking Women Producers and Workess with global markets, 134-164.

3. Mahmud, RB. (2012), "Skills development in Bangladesh RMG sector", The Newsa Today, http://www.newstoday.com.bd 
4. Bhattacharya, D. and M. Rahman. (2000). Bangladesh's Apparel Sector: Growth Trends and the Post-MFA Challenges. Proceedings of a national seminar on Growth of Garment Industry in Bangladesh: Economic and Social Dimensions, BIDS and OXFAM-GB Bangladesh, Dhaka.

5. Barkat, A., Ahmed, S.N., Maksud, A.K.M., Ali, M.A. (2003). The cost for woman workers of precarious employment in Bangladesh. Human Development Research Centre; Oxfam GB.

6. Muschalla, B. and Linden, M. (2009). Workplace phobia-a first explorative study on its relation to established anxiety disorders, sick leave, and work-directed treatment. Psychology, health \& medicine, 14(5), pp.591-605.

7. Linden, M. and Muschalla, B. (2007). Anxiety disorders and workplace-related anxieties. Journal of anxiety disorders, 21(3), pp.467-474.

8. Muschalla, B., Heldmann, M. and Fay, D. (2013). The significance of job-anxiety in a working population. Occupational medicine, 63(6), pp.415-421.

9. Paletz, E. M., Slattery, M. J., Essex, M. J., Vanness, E. R., Infante, M., Rogers, G. M., \&Gern, J. E. (2011). Depression, anxiety, and dermatologic quality of life in adolescents with atopic dermatitis. The Journal of allergy and clinical immunology, 128(3), 668-671.

https://doi.org/10.1016/j.jaci.2011.05.003

10. Moukheiber A, Rautureau G, Perez-Diaz F, Soussignan R, Dubal S, Jouvent R, Pelissolo A. Gaze avoidance in social phobia: objective measure and correlates. Behav Res Ther. 2010 Feb;48(2):147-51. doi: 10.1016/j.brat.2009.09.012. Epub 2009 Oct 8. PMID: 19863948.

11. Gilbreath, B. and Benson, P.G. (2004). The contribution of supervisor behaviour to employee psychological well-being. Work \& Stress, 18(3), pp.255-266.
12. Wittchen, H.U., Jacobi, F., Rehm, J., Gustavsson, A., Svensson, M., Jönsson, B., Olesen, J., Allgulander, C., Alonso, J., Faravelli, C. and Fratiglioni, L. (2011). The size and burden of mental disorders and other disorders of the brain in Europe 2010. European Neuropsychopharmacology, 21(9), pp.655-679.

13. Sanne B, Mykletun A, Dahl AA, Moen BE, Tell GS. Testing the Job Demand-ControlSupport model with anxiety and depression as outcomes: the Hordaland Health Study. Occup Med (Lond). 2005 Sep;55(6):463-73. doi: 10.1093/occmed/kqi071. Epub 2005 Apr 21. PMID: 15845554.

14. Johnson DW, Johnson RT. An Educational Psychology Success Story: Social Interdependence Theory and Cooperative Learning. Educational Researcher. 2009;38(5):365-379. doi:10.3102/0013189X09339057

15. Kabeer, N and Mahmud, S. (2004). Rags, Riches and Women Workers: Exportoriented Garment Manufacturing in Bangladesh Chains of Fortune: Linking Women Producers and Workess with global markets, 134-164.

16. Brodsky, C.M. (1988). The psychiatric epidemic in the American workplace. Occupational medicine (Philadelphia, Pa.), 3(4), pp.653-662.

17. Hobson, J. and Beach, J.R. (2000). An investigation of the relationship between psychological health and workload among managers. Occupational Medicine, 50(7), pp.518-522.

18. Llena-Nozal, A., Lindeboom, M., Portrait, F. (2004). The effect of work on mental health: does occupation matter, Health Economics 13, 1045-1062.

19. Haslam, C., Atkinson, S., Brown, S.S. and Haslam, R.A. (2005). Anxiety and depression in the workplace: effects on the individual and organisation (a focus group 
investigation). Journal of affective disorders, 88(2), pp.209-215.

20. Muschalla, B. and Linden, M. (2009). Workplace phobia-a first explorative study on its relation to established anxiety disorders, sick leave, and work-directed treatment. Psychology, health \& medicine, 14(5), pp.591-605.

21. Nash-Wright, J. (2011). Dealing with anxiety disorders in the workplace: importance of early intervention when anxiety leads to absence from work. Professional case management, 16(2), pp.5559. 